\title{
Citrate Uptake into Pectobacterium atrosepticum Is Critical for Bacterial Virulence
}

\author{
Claude Urbany and H. Ekkehard Neuhaus \\ Pflanzenphysiologie, Technische Universität Kaiserslautern, Erwin Schrödinger Str., D-67653 Kaiserslautern, Germany \\ Submitted 2 October 2007. Accepted 2 January 2008.
}

\begin{abstract}
To analyze whether metabolite import into Pectobacterium atrosepticum cells affects bacterial virulence, we investigated the function of a carrier which exhibits significant structural homology to characterized carboxylic-acid transport proteins. The corresponding gene, ECA3984, previously annotated as coding for a $\mathrm{Na}^{+} /$sulphate carrier, in fact encodes a highly specific citrate transporter (Cit1) which is energized by the proton-motive force. Expression of the cit1 gene is stimulated by the presence of citrate in the growth medium and is substantial during growth of $P$. atrosepticum on potato tuber tissue. Infection of tuber tissue with $P$. atrosepticum leads to reduced citrate levels. $P$. atrosepticum insertion mutants, lacking the functional Cit1 protein, did not grow in medium containing citrate as the sole carbon source, showed a substantially reduced ability to macerate potato tuber tissue, and did not provoke reduced citrate levels in the plant tissue upon infection. We propose that citrate uptake into $P$. atrosepticum is critical for full bacterial virulence.
\end{abstract}

Additional keywords: pathogen resistance, Dickeya dadantii, Erwinia.

Enterobacteriaceae represent a large family of gram-negative bacteria that include some well-studied species. Among these, Pectobacterium atrosepticum, formerly named Erwinia carotovora subsp. atroseptica (Gardan et al. 2003), is known as an agronomically important member of phytopathogenic Enterobacteriaceae. $P$. atrosepticum either causes blackleg (stem rotting) under field conditions or serves as the causative agent for soft rotting of tubers under post-harvest conditions. In sum, $P$. atrosepticum provokes severe economic losses (Pérembelon and Kelman 1980).

In general, virulence genes of pathogenic bacteria can be divided into three major classes. Class I genes represent true virulence factors and encode enzymes involved in interaction with the host. These proteins are responsible, for example, for cell and tissue damage during the infection. Virulence-associated factors represent class II genes and act as regulators of virulence factor genes. Finally, class III genes encode so-called virulence life-style factors comprising proteins involved in host colonization, evasion of the host immune system, or sur-

Corresponding author: E. Ekkehard Neuhaus; Telephone: +49-631-2052372; Fax: +49-631-2052600; E-mail: neuhaus@ @rhrk.uni-kl.de

Present address of C. Urbany: Max Planck Institute for Plant Breeding, Carl von Linné-Weg 10, D-50825 Köln, Germany.

* The $\boldsymbol{e}$-Xtra logo stands for "electronic extra" and indicates that three supplemental figures and one supplemental table are published online. vival of the pathogen within the host tissue (Wassenaar and Gaastra 2001).

In $P$. atrosepticum, virulence genes belonging to class I (also called true virulence genes) encode mainly extracellular acting plant cell-wall-degrading enzymes, such as cellulases and various pectinases. These proteins are responsible for the substantial and rapid maceration of plant tissue infected by $P$. atrosepticum (Kelemu and Collmer 1993). Regulators involved in bacterial "quorum sensing" are examples of class II virulence factors and represent promising candidates for studying the molecular regulation of bacterial virulence (Burr et al. 2006; Eriksson et al. 1998; Harris et al. 1998; Henke and Bassler 2004; Thomson et al. 1997).

In addition to these obvious virulence determinants, further studies indicate the existence of a group of virulence genes involved in the provision of nutrients to the attacking $P$. atrosepticum cell. In this context, bacterial transport proteins can be considered to be class III genes because recent reports point to the importance of $P$. atrosepticum carriers for virulence (Barabote et al. 2003; Börnke et al. 2001; Gloux et al. 2005; Hugouvieux-Cotte-Pattat and Reverchon 2001; HugouvieuxCotte-Pattat et al. 2001).

In this context, the uptake of nutrient from the host tissue into plant pathogens can be considered to represent a critical process. In Arabidopsis, a highly efficient sugar transport protein is specifically synthesized upon wounding or elicitor treatment (Truernit et al. 1996). The wounding or elicitor-induced increase of plant-cell-wall associated invertases (Sturm and Chrispeels 1990) and the elicitor-stimulated activity of the plasma membrane-located P-ATPase (which is required to import sugars via $\mathrm{H}^{+}$/sugar cotransport) is clearly indicative of an increased competition of the host and the pathogen for limiting available nutrients.

However, potato mutants exhibiting reduced activities of the plastidic ATP/ADP transporter (Tjaden et al. 1998) show drastically increased resistance against $P$. atrosepticum and other pathogens (Conrath et al. 2003; Linke et al. 2002). This is remarkable because sugar levels are high in corresponding host tissue (Geigenberger et al. 2001) and, therefore, a restricted sugar availability cannot be the reason for the observed pathogen resistance.

Interestingly, a microarray analysis on Dickeya dadantii (formerly named $E$. chrysanthemii) revealed that several genes coding for transport proteins are specifically upregulated during infection of the host tissue (Okinaka et al. 2002). Because it appeared unlikely that sugar availability per se limits bacterial virulence (discussed above), we concentrated on $P$. atrosepticum transporters with the capability to import other highly abundant metabolites, namely carboxylic acids. A recent study revealed that the expression of a citrate transporter gene from Xanthomonas campestris pv. vesicatoria (citH homolog) is induced during 
interaction with tomato plants and is required for wild-type levels of virulence (Tamir-Ariel et al. 2007).

In the course of the analysis, we identified a so far not characterized citrate carrier (Cit1) from $P$. atrosepticum, verified the transport properties of the carrier protein Cit1, showed that the citl gene is highly expressed during infection of tuber tissue, and demonstrated that Cit 1 activity is critical for virulence of $P$. atrosepticum.

\section{RESULTS}

\section{Functional identification}

of a citrate-specific carrier protein in P. atrosepticum.

A previously made microarray analysis on the closely related species $D$. dadantii revealed that several genes coding for transport proteins were upregulated during infection of the plant tissue (Okinaka et al. 2002). One of the upregulated genes previously was predicted to code for a sodium-coupled sulphate carrier (Okinaka et al. 2002), but also shows high structural homology to various carboxylic acid carriers (discussed below). In fact, the corresponding protein family comprises both types of transporters, carboxylate and sulphate carriers (Saier 2000).
Therefore, we focused our attention on the biochemical function of a homologous $P$. atrosepticum protein. To identify the biochemical properties of the corresponding $P$. atrosepticum carrier, we first conducted a sequence alignment with functionally characterized transport proteins. Subsequent to this, we analyzed the transport characteristics of $P$. atrosepticum wild-type and insertion mutant cells lacking the intact transport protein gene (annotated as ECA3984) (Bell et al. 2004).

A detailed sequence analysis of the protein encoded by the gene ECA3984 (here named PaCit1, discussed below) revealed that this highly hydrophobic protein is 484 amino acids in length, exhibits 12 predicted transmembrane domains, and clusters phylogenetically closely to other carboxylic acid transporters (Fig. 1). PaCit1 exhibits the highest sequence identity to functionally characterized carboxylate carrier proteins (ranging from 40 to $56 \%$ ) and shares with these proteins a substantial number of conserved protein domains (Fig. 1; data not shown). In addition to the Escherichia coli citrate carrier CitT (Pos et al. 1998) and the carboxylate carrier SoDit1 from spinach plastids (Weber et al. 1995), two further bacterial transporters (Sa2oxo and StCat) with high structural homology to PaCit1 were identified (Fig. 1). In the P. atrosepticum genome,
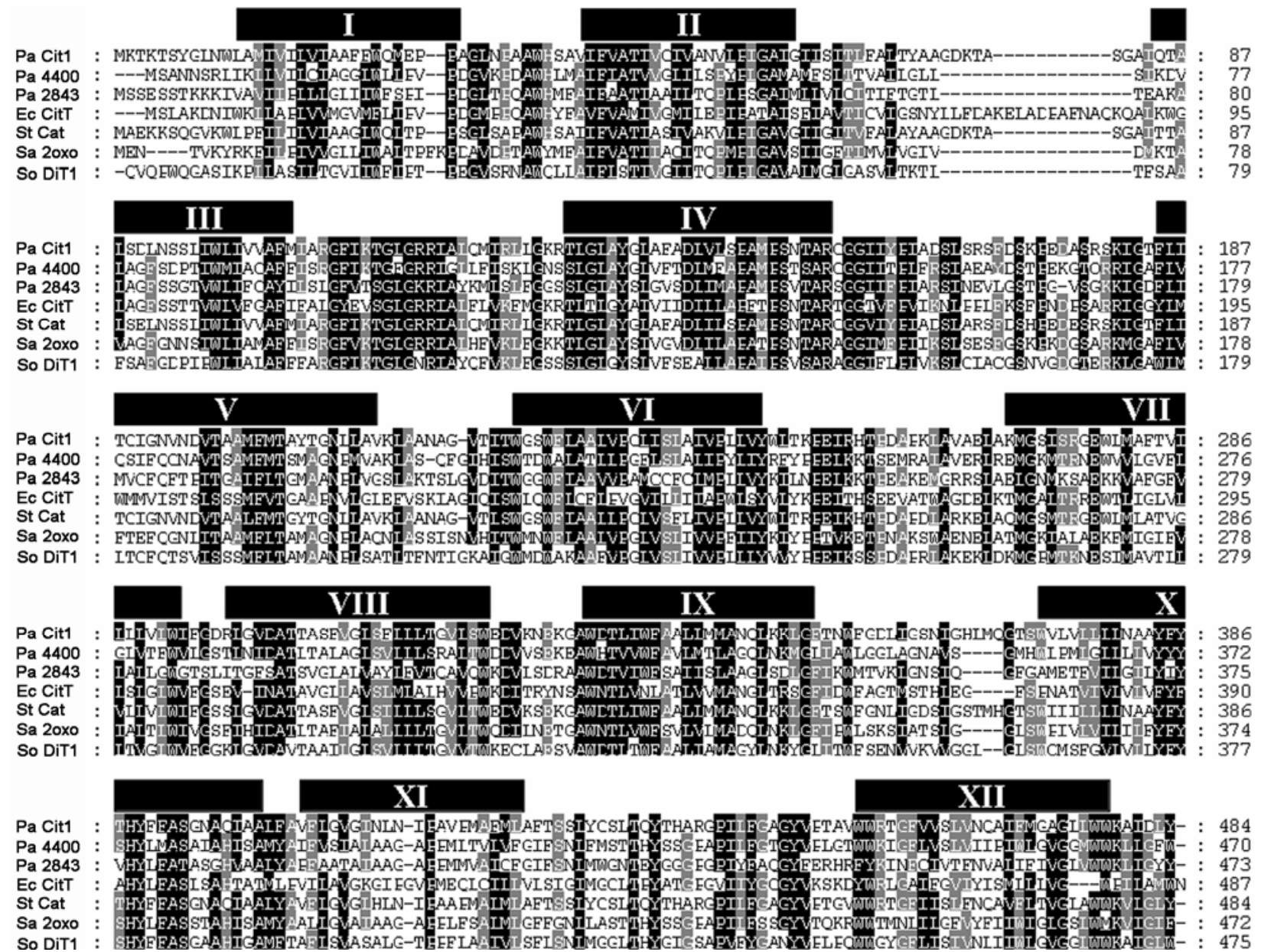

Fig. 1. Alignment of PaCit1 with homologous proteins. The amino-acid residues identical or similar among at least six proteins of the alignment are indicated by black shading and residues conserved by five proteins are marked by gray shading. The regions representing predicted transmembrane helices are marked by black bars (calculated by TMpred) (Hofmann and Stoffel 1993). The dashes represent gaps introduced to improve the similarity between the proteins. The first $100 \mathrm{~N}$-terminal residues of the SoDIT1-protein containing the plastidic transit peptide were truncated in order to improve the alignment. Numbers indicate the relative amino acid positions. ECA3984, putative sodium/sulfate symporter (renamed as PaCit1), Pectobacterium atrosepticum (accession number CAG76881); ECA4400, putative sodium/sulfate symporter, P. atrosepticum (accession number CAG77296); ECA2843, putative sodium/sulfate symporter, P. atrosepticum (accession number CAG75743); EcCitT, citrate carrier, Escherichia coli O157:H7 (accession number AAG54947); StCat, putative cation transporter, Salmonella choleraesuis (accession number AAX67016); Sa2oxo, 2-oxoglutarate-malate translocator, Staphylococcus aureus (strain bovine RF122) (accession number CAI82259); and SoDIT1, 2-oxoglutarate/malate translocator, chloroplast precursor, Spinacia oleracea (accession number AAA68148). 
two further homologs to PaCit1, annotated as ECA4400 and ECA2843, exist (Fig. 1).

In sum, these data might be taken as in silico indications that PaCit1 is a carboxylate carrier and not a sodium-coupled sulfate transport protein, as previously supposed (Bell et al. 2004; Okinaka et al. 2002).

\section{Expression pattern of the $\boldsymbol{P}$. atrosepticum cit1 gene.}

Pacit1 mRNA accumulation is obvious during bacterial growth in Luria-Bertani (LB) medium but not in minimal medium containing polypectate as the sole carbon source (Fig. 2, lanes 1 and 2). In the presence of citrate as the sole carbon source, a low Pacit1 mRNA level is detectable (Fig. 2, lane 3). Interestingly, $P$. atrosepticum cells reisolated from infected potato tuber disks contained high levels of Pacit1 mRNA (Fig. 2, lane 4). Latter observation is fully consistent with the accumulation of the corresponding mRNA in $D$. dadantii cells during infection of the plant tissue (Okinaka et al. 2002).

\section{Functional characterization of the PaCit1 protein.}

To characterize the PaCit1 protein on the functional level, we generated a corresponding insertion mutant (Pacit1::kan) and verified both the growth rates and the citrate transport activity of this mutant in comparison with corresponding Pectobacterium wild-type cells.

For this, we created Pacit1::kan mutants by insertion of a kanamycin resistance cassette into the structural Pacitl gene (Supplemental Fig. 1). Mutagenesis of the Pacit1 locus was achieved by use of a novel suicide vector ( $\mathrm{pEco}$ ), based upon a modified pUC18 plasmid. $P$. atrosepticum wild-type cells were transformed with this vector containing the citl coding sequence, interrupted by a kanamycin resistance cassette. Following recombination, the screening for ampicillin-sensitive and kanamycin-resistant colonies (Burse et al. 2004) allowed the identification of an insertion mutant. Further polymerase chain reaction (PCR) studies confirmed the disruption of the Pacitl locus (Supplemental Fig. 2A and B). The resulting mutant, named Pacit1:.kan, contained an approximately 1,400-bp-long kanamycin cassette in the central portion of the Pacit1 gene.

$P$. atrosepticum wild-type cells, grown in minimal medium containing citrate as the sole carbon source, are able to import citrate and to use this compound for growth (Fig. 3A). In contrast, Pacit::kan mutants do not grow in the corresponding minimal medium (Fig. 3A) whereas both $P$. atrosepticum wildtype and Pacit::kan insertion mutants grow at nearly identical rates in LB medium (Fig. 3B). The latter result can be taken as a control and demonstrates that the absence of a functional Pacitl gene does not impair the basic physiological performance of $P$. atrosepticum per se.

Short-term uptake experiments show that $P$. atrosepticum wild-type cells grown in LB medium prior to the transport experiment import citrate with a complex time dependency. Within the first $100 \mathrm{~s}$ of incubation, citrate uptake appeared to be relatively slow, followed by a more rapid import until approximately $3 \mathrm{~min}$ of incubation (Fig. 3C). Subsequent to this, citrate uptake slowed down again (Fig. 3C). In contrast, Pacit1::kan mutants hardly imported labeled citrate above the background activity (Fig. 3C). This observation further confirms that $\mathrm{PaCit} 1$ represents a functional citrate carrier.

To get first indications on the substrate specificity, we analyzed the effect of excess unlabeled metabolites on PaCit1mediated citrate uptake (Fig. 3D). Several TCA cycle intermediates, carboxylic acids considered to be important plant metabolites, and highly abundant amino acids such as glutamine and glutamate were chosen as putative competitors.

Unlabeled citrate itself was the most efficient competitor, reducing the uptake of radioactive labeled substrate to approxi- mately $35 \%$ of the control rate (Fig. 3D). Excess malate in the incubation medium reduced the uptake of labeled citrate to only approximately $80 \%$ of the control uptake rate (Fig. 3D). Other carboxylic acids such as fumarate, succinate, and acetate hardly inhibited PaCit1-mediated $\left[{ }^{14} \mathrm{C}\right]$-citrate uptake (Fig. 3D). All other metabolites tested did not affect citrate transport significantly (Fig. 3D). Interestingly, the protonophore m-chlorophenylhydrazone (CCCP) nearly abolished PaCit1-mediated citrate import into P. atrosepticum wild-type cells (Fig. 3D).

\section{Virulence efficiency of $\boldsymbol{P}$. atrosepticum mutants lacking the functional Cit1 protein.}

We demonstrated above that PaCit1 catalyzes citrate transport (Fig. 3A through D), that Pacit1::kan mutants do not import citrate (Fig. 3C and D), and that citl mRNA accumulates substantially during growth of $P$. atrosepticum on potato tuber tissue (Fig. 2, lane 4). Therefore, it was interesting to reveal whether PaCit1 may have a function in the virulence of $P$. atrosepticum. To test this hypothesis, we analyzed whether the absence of a functional PaCit1 protein affects the bacterial maceration efficiency.

Wild-type $P$. atrosepticum cells macerated approximately $50 \%$ of the formerly intact potato tuber tissue within $24 \mathrm{~h}$ of incubation, whereas Pacit1::kan cells macerated only $15 \%$ of the tuber tissue (Fig. 4A). To prove that the reduced virulence relies upon the absence of a functional citl gene, the maceration studies on potato tubers were extended by a complemented Pacit1::kan mutant (named cit1-Comp). Complemented Pacit1::kan cells, carrying a plasmid with an intact copy of the Pacitl gene under control of its native promoter (Supplemental Fig. 3), exhibited nearly the same virulence as wild-type cells. After inoculation of tuber disks with complemented mutants (cit1-Comp), approximately $50 \%$ of the tissue was macerated (Fig. 4A).

Following the determination of the Pacit1::kan virulence, the number of CFU after tissue inoculation with the corresponding bacterial strains was investigated. CFU values of wild-type $P$. atrosepticum as well as cit1-Comp cells were approximately $2.3 \times 10^{8}$ bacterial cells per tuber disk (Fig. 4B). Interestingly, the number of viable bacteria recovered form tuber disks inoculated with Pacit1::kan mutant cells exhibited a significant reduction compared with the CFU obtained in inoculations with wild-type or complemented Pacit1::kan cells (Fig. 4B).

Citrate levels in potato tubers infected with $P$. atrosepticum.

To analyze whether $P$. atrosepticum takes up citrate during infection of potato tuber tissue, we quantified citrate levels in tuber disks within the first $12 \mathrm{~h}$ of infection.

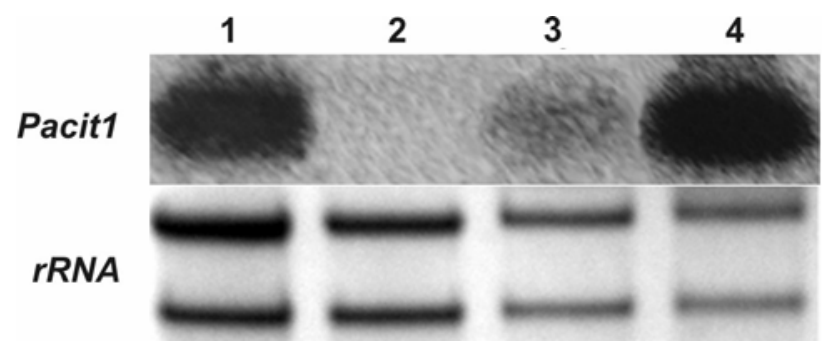

Fig. 2. RNA gel blot analysis showing Pacitl transcript accumulation. Total RNA was extracted from Pectobacterium atrosepticum wild-type cells grown under different conditions. Cells grown in the corresponding medium were harvested by centrifugation after reaching mid-log phase. P. atrosepticum cells grown on potato tuber disks were harvested after $24 \mathrm{~h}$. Lane 1, LuriaBertani medium; lane 2, polypectate minimal medium; lane 3, M9 minimal medium supplemented with $10 \mathrm{mM}$ citrate; and lane 4, P. atrosepticum cells grown and isolated from tuber disks $(n=4)$. rRNA represents loading controls. 
Freshly prepared potato tuber disks contained approximately $7.8 \mu$ mole citrate per gram of fresh weight ( $\mathrm{gFw}$ ) (Fig. 5). This level is slightly decreased after $6 \mathrm{~h}$, approaching $7.5 \mu \mathrm{mole} / \mathrm{gFw}$, and, at $12 \mathrm{~h}$ post preparation, citrate was present at a level of 6 $\mu$ mole/gFw (Fig. 5). The infection of freshly prepared tuber disks with $P$. atrosepticum wild-type cells reduced the endogenous citrate level substantially. After $6 \mathrm{~h}$ of infection, citrate approached approximately $6 \mu \mathrm{mole} / \mathrm{gFw}$ and, $12 \mathrm{~h}$ after infection, tuber citrate levels were approximately $3.5 \mu$ mole/gFw (Fig. 5). Tuber tissue inoculated with the Pacit1::kan mutant exhibited citrate levels after 6 or $12 \mathrm{~h}$ of infection similar to those observed in noninfected control disks (Fig. 5). This decrease was specific because malate levels in prepared potato tuber disks were not affected by the presence of $P$. atrosepticum wild-type or Pacit1::kan cells (data not shown).

\section{DISCUSSION}

From a structural point of view (Fig. 1), PaCit1 joins the large family of the so-called divalent anion sodium symporters (DASS) (Pajor 2006; Saier 2000). Members of this carrier family exist in all eukaryotes and a wide number of prokaryotic species, and several homologous proteins have been characterized on the functional level (Emmerlich et al. 2003; Hall and Pajor 2007; Pajor 1999; Pos et al. 1998; Weber et al. 1995).
Interestingly, the homologous protein from $E$. coli $(E c \mathrm{CitT})$ and the chloroplastic carrier SoDit1 from spinach chloroplasts catalyze a counter exchange mode of transport (Menzlaff and Flügge 1993; Pos et al. 1998). In marked contrast, PaCit1 most likely catalyzes net citrate uptake and is energized by a proton motive force rather than by an $\mathrm{Na}^{+}$gradient. The latter conclusion is based on two observations. First, PaCit1 allows $P$. atrosepticum to grow on minimal medium containing citrate as the sole carbon source (Fig. 4A). This growth is dependent upon a net carbon uptake. Second, the protonophore CCCP prevents PaCit1-mediated citrate transport (Fig. 4D), and proton dependency is a typical feature of carriers allowing transport of substrates against an existing concentration gradient.

Although the biochemical characteristics of PaCit1 are in line with other bacterial transport proteins catalyzing net citrate uptake (e.g., the $\mathrm{Na}^{+}$-dependent citrate carrier $\mathrm{CitS}$ from Klebsiella pneumoniae) (van der Rest et al. 1992), PaCit1, to our knowledge, is the first bacterial citrate transporter of the DASS carrier family characterized on the functional level. The only DASS member able to catalyze net citrate uptake besides PaCit1 is the mammalian sodium-coupled transporter NaCT (Inoue et al. 2002). The latter carrier and the SdcS protein from Staphylococcus aureus-responsible in dicarboxylate uptake-both depend upon an electrochemical $\mathrm{Na}^{+}$gradient. However, the fact that PaCit1 does not depend upon a sodium
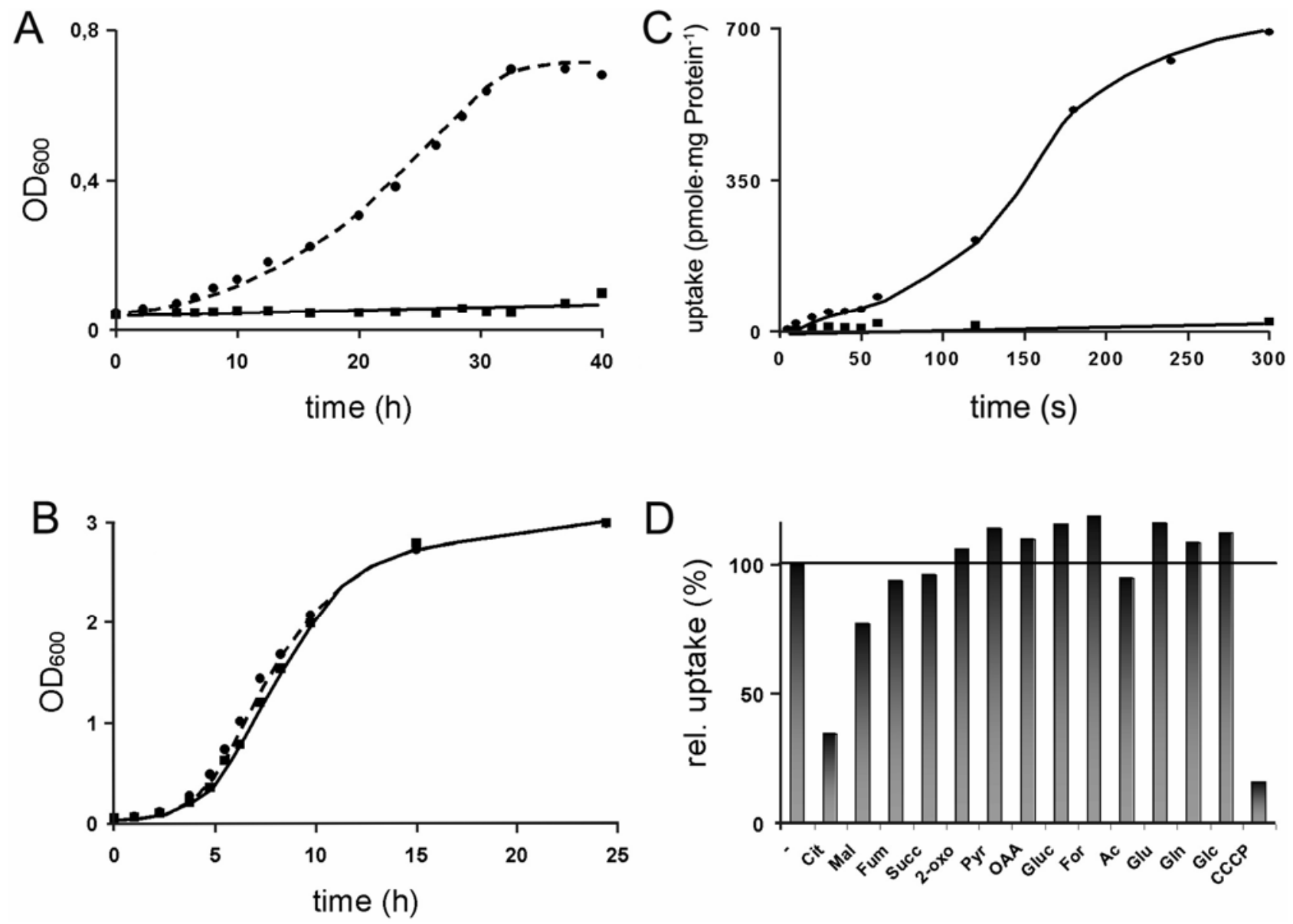

Fig. 3. Biochemical characterization of the PaCit1 protein. A, Growth of Pectobacterium atrosepticum wild-type (•) and Pacit1::kan mutant cells (ם) in M9

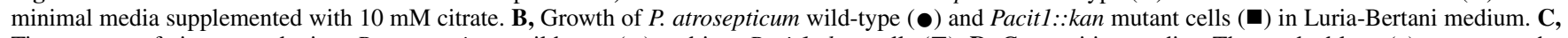
Time course of citrate uptake into $P$. atrosepticum wild-type $(\bullet)$ and into Pacit1::kan cells (ם). D, Competition studies. The marked lane (-) represents the uptake of citrate $(25 \mu \mathrm{M})$ after $3 \mathrm{~min}$ in the absence of any competitor substance (set to $100 \%)$. Given competitors were added in a 10 -fold excess $(250 \mu \mathrm{M})$. The protonophore m-chlorophenylhydrazone (CCCP) was present at a final concentration of $50 \mu \mathrm{M}$. Data present means of three independent experiments (each with five technical replicates). Standard error of the mean was always less than $8 \%$ of the given mean value. Abbreviations used: rel. uptake $=$ relative

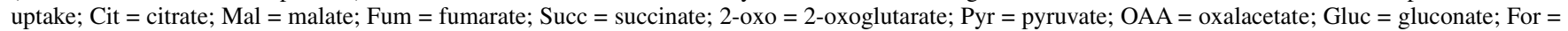
formiate; $\mathrm{Ac}=$ acetate; Glu = glutamate; Gln = glutamine; and Glc = glucarate . 
gradient is consistent with the generally low sodium levels in higher plants (Zhu 2002).

In general, a precondition for an efficient use of host-derived metabolites for pathogen metabolism is the fast access to corresponding compounds after entering the plant tissue. In this context, citrate represents a suitable candidate metabolite because it typically accumulates at appreciable concentrations in the plant apoplast (Kania et al. 2003). Moreover, it appears likely that $P$. atrosepticum imports citrate because the presence of this metabolite in the growth medium correlates with the accumulation of Pacitl mRNA and because, upon infection of potato tuber tissue, Pacit1 mRNA accumulates at very high levels (Fig. 2, lanes 3 and 4).

The fact that Pacit1 mRNA accumulation is comparably low in citrate-containing medium (Fig. 2, lane 3) but high during infection of tuber tissue (Fig. 2, lane 4) indicates that further plant-derived signals enhance expression of the Pacitl gene. The low level of Pacitl mRNA in citrate-containing medium also could be explained in terms of the respective growth rates. $P$. atrosepticum showed growth with the lowest rates on citratecontaining M9 medium, followed by medial growth rates in polypectate-containing minimal medium and high growth rates
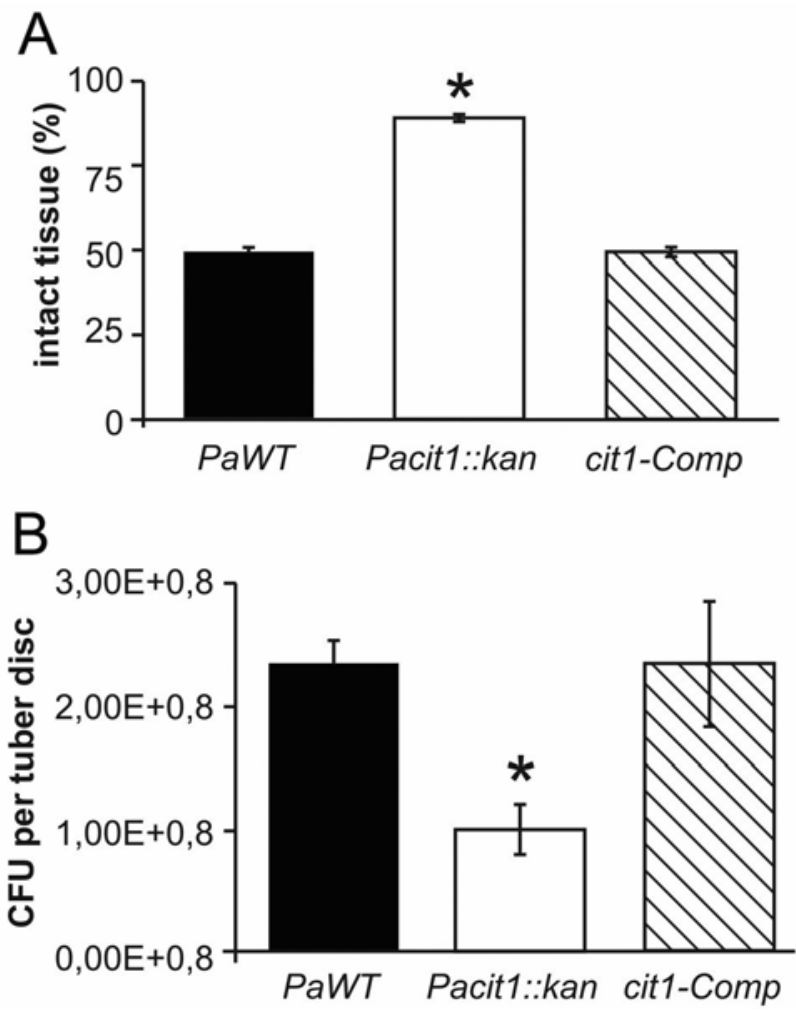

Fig. 4. Dependency of Pectobacterium atrosepticum virulence and growth on the PaCit1 protein. A, Tuber slice maceration assays. Slices were inoculated with 8,000 bacterial cells and incubated in a moisture-saturated petri dish for $24 \mathrm{~h}$ at $23^{\circ} \mathrm{C}$. The figure shows the percentage of intact tissue left by the wild type (PaWt), the Pacit1::kan insertional mutant, and the complemented mutant (cit1-Comp). Values are the means of five independent assays (each with four technical replicates). Root mean square deviations are indicated by black bars. B, Determination of CFU per tuber disk after maceration and growth of $P$. atrosepticum strains. Tuber disks were inoculated with corresponding strains as described above. After $24 \mathrm{~h}$, disks were suspended in $4 \mathrm{ml}$ of $\mathrm{NaCl}$ solution $(0.9 \%)$ and several dilutions were plated onto Luria-Bertani agar plates. Colonies were counted and given as CFU per tuber disk. Starting population levels were the same for each strain. Values represent means of three independent experiments (each with seven technical replicates) with corresponding root mean square deviations. Statistically significant differences between strains are indicated by an asterisk. in complete LB medium (data not shown). Thus, the absence of detectable Pacitl mRNA in cells grown in polypectatecontaining medium (Fig. 2, lane 2) reflect a specific adaptation to environmental conditions making Pacitl expression dispensable.

Twelve hours after tuber tissue infection by $P$. atrosepticum, citrate levels are specifically reduced (Fig. 5 and above). Later observation and the response of the Pacitl gene during tissue infection (Fig. 2, lane 4) indicate that increased Pacitl mRNA is accompanied by active PaCit1 protein. The still-appreciable citrate levels in tuber tissue after $12 \mathrm{~h}$ of infection (Fig. 5) do not contradict our assumption of an active PaCit1 protein. In plant cells, citrate is present in mitochondria, in the cytosol, and in the large storage vacuole (Gerhardt et al. 1987; Hurth et al. 2005; Kania et al. 2003; Martinoia and Rentsch 1992). Obviously, even the efficient bacterial citrate uptake system PaCit1 (Fig. 3) cannot completely empty the large and separated citrate pools. Because the TCA cycle constitutes an indispensable pathway in plants, the depletion of associated metabolites probably is avoided by the plant cell.

The high level of Pacitl mRNA under conditions of tuber tissue maceration (Fig. 2) can be taken as first evidence that PaCit1 fulfils an important function for the virulence of $P$. atrosepticum (Fig. 2). In addition, the observation that a corresponding insertion mutant exhibits markedly reduced maceration efficiency (Fig. 4A) although showing an unaltered basic physiological capability (Fig. 3B) further substantiates the specific integration of PaCit1 in P. atrosepticum virulence. However, at this time, we should discuss various possibilities to explain how an active PaCit1 protein might contribute to $\mathrm{Pec}$ tobacterium virulence:

First, during infection of plant tissue, iron acquisition is a limiting factor for Pectobacterium spp. And, to circumvent iron deficiency, this pathogen must synthesize the iron chelator

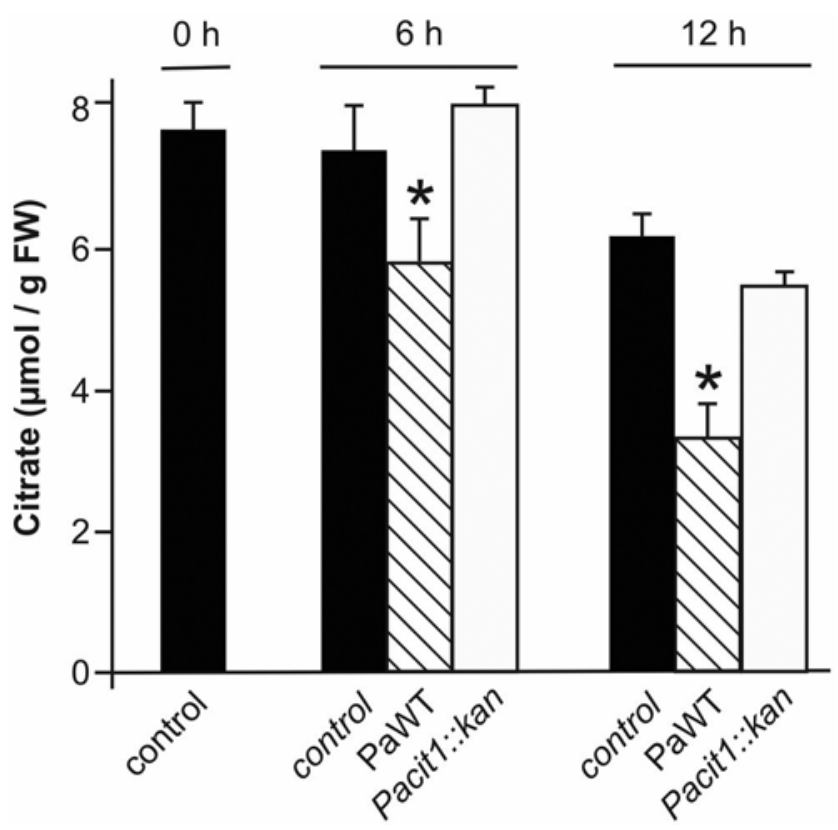

Fig. 5. Citrate levels in potato tuber disks inoculated with Pectobacterium atrosepticum. Tuber disks were punched out of freshly harvested, fully developed potato tubers. The metabolism was stopped immediately after preparation of the tuber disks $(0 \mathrm{~h})$ or after inoculation of the tuber disks with $8 \times 10^{3} \mathrm{CFU}$ and subsequent incubation for 6 or $12 \mathrm{~h}$ in a moisturesaturated petri dish at $23^{\circ} \mathrm{C}$. Data present means of three independent experiments (each with four biological technical replicates). Standard error of the mean was always less than $8 \%$ of the given mean value. Tuber citrate levels with statistically significant differences at a given time point depending on the strain used for inoculation are marked by an asterisk. 
achromobactin. Achromobactin is a citrate-based chelator (Munzinger et al. 2000) and it has been shown that synthesis of this compound in the closely related species $D$. dadantii is critical for plant infection (Franza et al. 2005). Assuming that the endogenous citrate biosynthesis in P. atrosepticum is limited, an exogenous supply would facilitate the generation of the essential iron chelator achromobactin.

Second, because pathogenesis by Pectobacterium spp. partially proceeds under anoxic conditions, especially in the early stages of tissue maceration (Smid et al. 1993), an impaired bacterial TCA cycle could be compensated by citrate uptake via PaCit1. It is not clear whether and to what extent bacterial anaerobic metabolism takes place during tuber maceration. However, switching from aerobic to anaerobic energy pathways is an important aspect of bacterial pathogenesis (Tang et al. 2005; Vasil 2007). Therefore, citrate import by Cit1 might be part of this complex and adaptable machinery, allowing $P$. atrosepticum to deal with the specific environment within the host tissue and the corresponding metabolite spectrum.

Third, a decrease of tuber citrate caused by uptake into Pectobacterium spp. might impair the plant defence reaction. This assumption is based on recent findings showing that the TCA cycle is involved in homeostasis of reactive oxygen species (ROS) (Baxter et al. 2007; Mailloux et al. 2007). Therefore, a depletion of plant citrate levels through uptake via PaCit1 could hinder a TCA-cycle-dependent ROS homeostasis as being part of the plant resistance reaction.

Finally, in addition to citrate, carbon sources other than carboxylic acids also are available in potato tubers, especially in highly $P$. atrosepticum-resistant potato tubers (Geigenberger et al. 2001). However, inactivation of citrate uptake by insertional mutagenesis of citl correlated with a significant decrease of maceration efficiency of approximately 50\% (Fig. 4A). Remarkably, a recent study identified a predicted citrate transport protein from $X$. campestris pv. vesicatoria (named citH) as required for wild-type levels of virulence (Tamir-Ariel et al. 2007). Therefore, citrate uptake systems in Xanthomonas and Pectobacterium spp. are required for full virulence. This observation points to the general importance of this carboxylic acid for both species, representing plant pathogens with different lifestyles.

According to our study, Cit1 joins this group of virulenceaffecting proteins and it will be interesting to identify the exact factors governing expression of the citl gene. The observation that citl gene expression is stimulated by the presence of citrate in the medium (Figs. 2 and 3A) might be taken as an indication that citrate per se is sensed by $P$. atrosepticum. Such perception would make sense because, in contrast to the situation in soil, the citrate levels in the plant apoplast are substantial (Kania et al. 2003) and would signal the pathogen that it entered the correct host environment.

\section{MATERIALS AND METHODS}

\section{Bacterial strains, plasmids, and culture conditions.}

Strains and plasmids used in this study are listed in Supplemental Table 1. E. coli strain XL-1 Blue was cultured in LB medium at $37^{\circ} \mathrm{C}$. P. atrosepticum was cultured in LB medium or pectate minimal medium consisting of $0.2 \% \mathrm{wt} / \mathrm{vol}) \mathrm{NH}_{4} \mathrm{SO}_{4}$, $0.4 \%$ (wt/vol) $\mathrm{KH}_{2} \mathrm{PO}_{4}, 0.6 \%$ (wt/vol) $\mathrm{Na}_{2} \mathrm{HPO}_{4}, 0.02 \%$ (wt/vol) $\mathrm{MgSO}_{4}, 0.0001 \%$ (wt/vol) $\mathrm{FeSO}_{4} \cdot \mathrm{H}_{2} \mathrm{O}, 0.0001 \%$ (wt/vol) $\mathrm{CaCl}_{2}$, and $0.1 \%(\mathrm{wt} / \mathrm{vol})$ pectate, $\mathrm{pH}$ adjusted to 6.7 , at $28^{\circ} \mathrm{C}$. Nutrient agar plates were obtained by supplementing culture media with $1.5 \%$ agar when required. Screening for growth on citrate was performed on Simmons citrate agar (Simmons 1926). Growth experiments for citrate utilization were accomplished in M9 minimal medium (Sambrook et al. 1989), supplemented with $10 \mathrm{mM}$ citrate. Where appropriate, media were supplemented with antibiotics at the following concentrations: ampicillin $\left(200 \mu \mathrm{g} \mathrm{ml}^{-1}\right)$ and kanamycin $\left(50 \mu \mathrm{g} \mathrm{ml}^{-1}\right)$.

\section{DNA manipulations, mutagenesis, and complementation studies on $P$. atrosepticum.}

Molecular biological techniques were performed according to (Sambrook et al. 1989). Mutagenesis of P. atrosepticum was achieved by a suicide vector based on the pUC18 cloning plasmid. To convert the pUC18 vector in a nonreplicable suicide vector, a supplemental EcoRI site was introduced by sitedirected mutagenesis (Stratagene, La Jolla, CA., U.S.A.) using the primers $p E c o l$ (5'-GACGCTCAGTGGAACGAGAATTC ACGTTAAGGGATTTTGG-3') and $p E c o 2$ (5'-CCAAAATCC CTTAACGTGAATTCTCGTTCCACTGAGCGTC-3'). The derived plasmid, annotated as $p E c o$, is characterized by two $E c o$ RI sites flanking the origin of replication. After amplification of the ECA3984 gene using Pfu-polymerase (Promega Corp., Madison WI., U.S.A.) and the primers cits (5'-CCCGA TTAAGGAAAACATATGAAGACC-3') and citas (5'-CATCT ATTAGCTCGAGATCAATACAGGTCG-3'), the product was cloned into a blunted $p E c o$ plasmid, yielding pPa5. By a $B m g \mathrm{BI}$ digestion, an approximately 350-bp-long fragment was eliminated and replaced by a blunted PvuII fragment of a modified $p U C_{-} K a n$ plasmid ( $p U C_{-}$Kan-EcoRI), consisting of a kanamycin resistance cassette (Amoroso et al. 2003). The resulting plasmid, pPa6, can be converted at any time into the corresponding suicide vector by an EcoRI restriction, followed by religation of the remaining plasmid without the origin of replication. This religated construct was transformed into $P$. atrosepticum wild-type cells by electroporation. Cells were allowed to recover for $1 \mathrm{~h}$ at room temperature in $\Psi \mathrm{B}$ medium (Sambrook et al. 1989).

Pacit1::kan deletion mutants were identified by screening for kanamycin-resistant and ampicillin-susceptible colonies. These colonies were further characterized by PCR screening using the cits/as primer pair and the kanamycin primers $K s\left(5^{\prime}\right.$ GCTGATTTATATGGGTATAAATGGGCTCGC-3') and Kas (5'-GGAGAAAACTCACCGAGGCAGTTCCATAG-3'), as well as the locus specific primer cit500s (5'-GGACAGATC GAATGTCAGAATTC-3').

For complementation, a DNA fragment of $1,580 \mathrm{bp}$ was amplified by use of the primers 3984prom (5'-CCAAATCAA TAAGCCGAC- $3^{\prime}$ ) and citas (5'-CATCTATTAGCTCGAGATC AATACAGGTCG-3'), consisting of the ECA3984 gene under control of its native promoter using the $P f u$-polymerase (Promega Corp.). The latter DNA was cloned into a blunted $p B S K$ vector (Stratagene) yielding the complementation construct pPa7. This plasmid was transformed into Pacit $1:: k a n$ deletion mutants. Complemented mutants were identified by screening for kanamycin-resistant, ampicillin-resistant, and citrate-positive colonies. These colonies were further characterized by PCR with T7 standard primers, resulting in the amplification of the insert harbored by pPa7. The amplified fragments were subjected to sequence analysis. Furthermore, restriction analysis was carried out after retransformation of plasmid DNA isolated from complemented Pacit1::kan mutant cells into E. coli XL-1 Blue. An EcoRI restriction is indicative for the presence of the $\mathrm{pPa} 7$ complementation construct.

\section{RNA preparation and RNA gel-blot analysis.}

For RNA preparation from $P$. atrosepticum, cells were grown in respective media to an optical density at $600 \mathrm{~nm}$ $\left(\mathrm{OD}_{600}\right)$ of 0.7 to 1 and directly snap frozen in liquid $\mathrm{N}_{2}$. In case of cultivation on potato tuber disks, $P$. atrosepticum cells were inoculated as described above. After incubation for $24 \mathrm{~h}$ at $23^{\circ} \mathrm{C}$, tubers were resuspended in sterile $\mathrm{H}_{2} \mathrm{O}$ and bacteria 
were reisolated from potato tissue by centrifugation (short spins). Supernatants, containing the $P$. atroseptica cells, were transferred into a new reaction vessel and directly shock frozen. Total RNA was isolated using a standardized method (Chomczynski 1993).

For RNA preparation from potato tuber disks, tissue was directly snap frozen in liquid nitrogen until RNA extraction using the Purescript RNA extraction kit (Gentra Systems, Minneapolis, MN, U.S.A.). For RNA gel-blot hybridization analysis, 15 $\mu \mathrm{g}$ (P. atroseptica) or $10 \mu \mathrm{g}$ (potato) of total RNA was denatured and separated on a $1.2 \%(\mathrm{wt} / \mathrm{vol})$ agarose- $2.5 \%(\mathrm{vol} / \mathrm{vol})$ formaldehyde gel (Linke et al. 2002).

\section{Transport assays.}

To analyze transport properties of PaCit1, wild-type $P$. atroseptica cells were grown in $\mathrm{LB}$ medium to an $\mathrm{OD}_{600}$ of 0.7 to 1 . Cells were harvested and resuspended in $50 \mathrm{mM}$ MESTRIS buffer medium ( $\mathrm{pH}$ 6.8) to an $\mathrm{OD}_{600}$ of 10, kept at room temperature, and subsequently used for uptake experiments. The transport assays were performed according to Pos and associates (1998). Briefly, uptake was allowed for indicated time spans at $30^{\circ} \mathrm{C}$ and was terminated by adding $0.9 \mathrm{ml}$ of ice-cold $0.1 \mathrm{M} \mathrm{LiCl}$ to $0.1 \mathrm{ml}$ of reaction mixture. Removal of external radioactively labeled substrate was achieved by transfer of the cells onto $0.45 \mu \mathrm{m}$ nitrocellulose filters, prewetted with 50 $\mathrm{mM}$ morpholineethanesulfonic acid (MES)-TRIS buffer medium, and set under vacuum. The cells were washed immediately with a further milliliter of $0.1 \mathrm{M} \mathrm{LiCl}$ solution and filters were transferred into $20-\mathrm{ml}$ scintillation vessels containing 10 $\mathrm{ml}$ of scintillation cocktail. Radioactivity in the samples was quantified in a scintillation counter (Tricarb 2500, CanberraPackard, Heidelberg, Germany).

Competition uptake assays were performed with $25 \mu \mathrm{M}$ radioactively labeled citrate and indicated competitors were added at a final concentration of $250 \mu \mathrm{M}$. CCCP was added to a final concentration of $50 \mu \mathrm{M}$.

\section{Cultivation of potato plants.}

Wild-type potato plants (Solanum tuberosum var. Désireé) were grown in a greenhouse in soil at $22^{\circ} \mathrm{C}$ during the day and $18^{\circ} \mathrm{C}$ at night and were watered daily. The ambient light was extended to $16 \mathrm{~h}$ per day with Philips Sont-Agro lights (200 $\mu \mathrm{E})$ as described before (Tjaden et al. 1998). Potato tissues used for metabolite quantification and for analysis of resistance against $P$. atrosepticum were harvested from fully developed tubers.

\section{Measurement of maceration activity and potato tuber slice assays.}

$P$. atrosepticum cells were grown in minimal medium overnight at $28^{\circ} \mathrm{C}$. To monitor the infection of potato tubers by $P$. atrosepticum, disks of $3 \mathrm{~mm}$ in thickness and $2 \mathrm{~cm}$ in diameter were punched out of tubers and incubated in plastic boxes under high humidity (Düring et al. 1993; Linke et al. 2002). Bacterial inoculation was done by transferring $8 \times 10^{3} \mathrm{CFU}$ in 10 $\mu \mathrm{l}$ of sterilized water to the center of the prepared tuber disks (Linke et al. 2002). Subsequently, the disks were incubated for $24 \mathrm{~h}$ at $23^{\circ} \mathrm{C}$ in the dark. For quantitative analysis of $P$. atrosepticum infections, the tuber disks were weighted and the macerated tissue was removed by washing off in a stream of tap water (Düring et al. 1993; Linke et al. 2002). A second determination of weight allowed quantification of the lost (macerated) tissue.

\section{Determination of potato tuber metabolite concentrations.}

Tuber slices taken from potato were prepared as described for $P$. atrosepticum inoculation assays and metabolism was stopped by the immediate transfer of the samples into liquid nitrogen. Frozen tuber disks were ground in $1 \mathrm{ml}$ of $90 \%$ ethanol in a precooled mortar. The resulting preparation was separated by centrifugation for $1 \mathrm{~min}(13,000 \times g)$ at $4^{\circ} \mathrm{C}$. Supernatants were transferred into a new reaction vessel and used for enzymatic metabolite quantifications (Passonneau and Lowry 1993). Metabolite recoveries were always above $92 \%$.

\section{Statistics.}

Statistical testing on tuber tissue maceration, CFU experiments, and tuber citrate levels was carried out using the SPSS software (SPSS Inc., Chicago). Data showing a $P$ value $<0.01$ in an independent $t$ test were considered as significantly different.

\section{ACKNOWLEDGMENTS}

This work was supported by the Deutsche Forschungsgemeinschaft (NE 418/4-3) and by the Federal State Rheinland-Pfalz (Nano Bio-Center, Kaiserslautern). We thank W. Jeblick (TU Kaiserslautern) for metabolite quantifications and gratefully acknowledge critical reading of the manuscript by T. Colby.

\section{LITERATURE CITED}

Amoroso, G., Seimetz, N., and Sültemeyer, D. 2003. The dc13 gene upstream of ictB is involved in rapid induction of the high affinity $\mathrm{Na}^{+}$-dependent $\mathrm{HCO}_{3}^{-}$transporter in cyanobacteria. Photosynth. Res. 77:127138.

Barabote, R. D., Johnson, O. L., Zetina, E., San Francisco, S. K., Fralick, J. A., and San Francisco, M. J. 2003. Erwinia chrysanthemi tolC is involved in resistance to antimicrobial plant chemicals and is essential for phytopathogenesis. J. Bacteriol. 185:5772-5778.

Baxter, C. J., Redestig, H., Schauer, N., Repsilber, D., Patil, K. R., Nielsen, J., Selbig, J., Liu, J., Fernie, A. L., and Sweetlove, L. J. 2007. The metabolic response of heterotrophic Arabidopsis cells to oxidative stress. Plant Physiol. 143:312-325.

Bell, K. S., Sebaihia, M., Pritchard, L., Holden, M. T., Hyman, L. J., Holeva, M. C., Thomson, N. R., Bentley, S. D., Churcher, L. J. C., Mungal, K., Atkins, R., Bason, R., Brooks, K., Chillingworth, T., Clark, K., Doggett, J., Fraser, A., Hance, Z., Hauser, H., Jagels, K., Moule, S., Norbertszak, H., Ormond, D., Price, C., Quail, M. A., Sanders, M., Walker, D., Whitehead, S., Salmond, G. P. C., Birch, P. R. J., Parkhill, J., and Toth, I. K. 2004. Genome sequence of the enterobacterial phytopathogen Erwinia carotovora subsp. atroseptica and characterization of virulence factors. Proc. Natl. Acad. Sci. U.S.A. 101:11105-11110.

Börnke, R, Hajirezaei, M.-R., and Sonnewald, U. 2001. Cloning and characterization of the gene cluster for palatinose metabolism from the phytopathogenic bacterium Erwinia rhapontici. J. Bacteriol. 183:24252430.

Bullock, W. O., Fernandez, J. M., and Short, J. M. 1987. XL1-Blue: A high efficiency plasmid transforming recA Escherichia coli strain with beta-galactosidase selection. Biotechniques 5:376-378.

Burr, T., A., Barnard, M., Corbett, M. J., Pemberton, C. L., Simpson, N. J., and Salmond, G. P. 2006. Identification of the central quorum sensing regulator of virulence in the enteric phytopathogen, Erwinia carotovora: The virR repressor. Mol. Microbiol. 59:113-125.

Burse, A., Weingart, H., and Ullrich, M. S. 2004. The phytoalexin-inducible multidrug efflux pump AcrAB contributes to virulence in the fire blight pathogen, Erwinia amylovora. Mol. Plant-Microbe Interact. 17:43-54.

Chomczynski, P. 1993. A reagent for the single step simultaneous isolation of RNA, DNA and protein from cell and tissue samples. Biotechniques 15:532-537.

Conrath, U., Linke, C., Jeblick, W., Geigenberger, P., Quick, W. P., and Neuhaus, H. E. 2003. Enhanced resistance to Phytophthora infestans and Alternaria solani in leaves and tubers, respectively, of potato plants with decreased activity of the plastidic ATP/ADP transporter. Planta 19:75-83.

Düring, K., Porsch, P., Fladung, M., and Lörz, H. 1993. Transgenic potato plants resistant to the phytopathogenic bacterium Erwinia carotovora. Plant J. 3:587-598.

Emmerlich, V., Linka, N., Reinhold, T., Hurth, M. A., Traub, M., Martinoia, E., and Neuhaus, H. E. 2003. The plant homolog to the human sodium/ dicarboxylic cotransporter is the vacuolar malate carrier. Proc. Natl. Acad. Sci. U.S.A. 100:11122-11126. 
Eriksson, A. R., Andersson, R. A., Pirhonen, M., and Pawlowski, K. 1998. Two component regulators involved in the global control of virulence in Erwinia carotovora subsp. carotovora. Mol. Plant-Microbe Interact. 11:743-752.

Franza, T., Mahe, B., and Expert, D. 2005. Erwinia chrysanthemi requires a second iron transport route dependent of the siderophore achromobactin for extracellular growth and plant infection. Mol. Microbiol. 55:261275

Gardan, L., Gouy, C., Christen, R., and Samson, R. 2003. Elevation of three subspecies of Pectobacterium carotovorum to species level: Pectobacterium atrosepticum sp. nov., Pectobacterium betavosculorum, Pectobacterium wasabiae sp. nov. Inv. Syst. Evol. Microbiol. 53:381-391.

Geigenberger, P., Stamme, C., Tjaden, J., Schulze, A., Quick, W. P., Betsche, T., Kersting, H. J., and Neuhaus, H. E. 2001. Tuber physiology and properties of starch from tubers of transgenic potato plants with altered plastidic adenylate transporter activity. Plant Physiol. 125:16671678.

Gerhardt, R., Stitt, M. N., and Heldt, H. W. 1987. Subcellular metabolite levels in spinach leaves. Regulation of sucrose synthesis during diurnal alterations in photosynthesis. Plant Physiol. 83:339-407.

Gloux, K., Touze, T., Pagot, Y., Jouan, B., and Blanco, C. 2005. Mutations of ousA alter the virulence of Erwinia chrysanthemi. Mol. PlantMicrobe Interact. 18:150-157.

Hall, J. A., and Pajor, A. M. 2007. Functional reconstitution of SdcS, a $\mathrm{Na}$-coupled dicarboxylate carrier protein from Staphylococcus aureus. J. Bacteriol. 189:880-885

Harris, S. H., Shih, Y. L., Bentley, S. D., and Salmond, G. P. C. 1998. The hexA gene of Erwinia carotovora encodes a LysR homologue and regulates motility and the expression of multiple virulence determinants. Mol. Microbiol. 28:705-717.

Henke, J. M., and Bassler, B. L. 2004. Three parallel quorum-sensing systems regulate gene expression in Vibrio harveyi. J. Bacteriol. 186:69026914.

Hofmann, K., and Stoffel, W. 1993. TMbase-a database of membrane spanning protein segments. Biol. Chem. 374:166-172.

Hugouvieux-Cotte-Pattat, N., and Reverchon, S. 2001. Two transporters, TogT and TogMNAB, are responsible for oligogalacturonide uptake in Erwinia chrysanthemi 3937. Mol. Microbiol. 41:1125-1132.

Hugouvieux-Cotte-Pattat, N., Blot, N., and Reverchon, S. 2001. Identification of TogMNAB, an ABC transporter which mediates the uptake of pectic oligomers in Erwinia chrysanthemi 3937. Mol. Microbiol. 41:1113-1123.

Hurth, M. A., Suh, S. J., Kretzschmar, T., Geis, T., Bregante, M., Gambale. F., Martinoia, E., and Neuhaus, H. E. 2005. Impaired pH homeostasis in Arabidopsis, lacking the vacuolar dicarboxylate transporter and analysis of carboxylic acid transport across the tonoplast. Plant Physiol. 137:901-910

Inoue, K., Zhuang, L., Maddox, D. M., Smith, S. B., and Ganapathy, V. 2002. Structure, function, and expression pattern of a novel sodiumcoupled citrate transporter $(\mathrm{NaCT})$ cloned from mammalian brain. J. Biol. Chem. 277:39469-39476.

Kania, A., Langlade, N., Martinoia, E., and Neumann, G. 2003. Phosphorus deficiency-induced modifications in citrate catabolism and in cytosolic $\mathrm{pH}$ as related to citrate exudation in cluster roots of white lupin. Plant Soil 248:117-127.

Kelemu, S., and Collmer, A. 1993. Erwinia chrysanthemi EC16 produces a second set of plant-inducible pectate lyase isozymes. Appl. Environ. Microbiol. 59:1756-1761

Linke, C., Conrath, U., Jeblick, W., Betsche, T., Mahn, A., Düring, K., and Neuhaus, H. E. 2002. Inhibition of the plastidic ATP/ADP-transporter protein primes potato tubers for augmented elicitation of defense responses and enhances their resistance against Erwinia carotovora. Plant Physiol. 129:1607-1615.

Mailloux, R. J., Beriault, R., Lemire, J., Singh, R., Chenier, D. R., Hamel, R. D., and Appanna, V. D. 2007. The tricarboxylic acid cycle, an ancient metabolic network with a novel twist. PLoS ONE 2, 1:e690.

Martinoia, E., and Rentsch, D. 1992. Uptake of malate and citrate into plant vacuoles. Pages 101-109 in: Transport and Receptor Proteins of plant Membranes. D. T. Cooke and D. T. Clarkson, eds. Plenum Press, New York.
Menzlaff, E., and Flügge, U. I. 1993. Purification and functional reconstitution of the 2-oxoglutarate/malate translocator from spinach chloroplasts. Biochim. Biophys. Acta 1147:13-18.

Munzinger, M., Budzikiewicz, H., Expert, D., Enard, C., and Meyer, J. M 2000. Achromobactin, a new citrate siderophore of Erwinia chrysanthemi. Z. Naturforsch. 55:328-332.

Okinaka, Y., Yang, Ch.-H., Perna, N. T., and Keen, N. T. 2002. Microarray profiling of Erwinia chrysanthemi 3937 genes that are regulated during plant infection. Mol. Plant-Microbe Interact. 15:619-629.

Pajor, A. M. 1999. Sodium-coupled transporters for Krebs cycle intermediates. Annu. Rev. Physiol. 61:663-682.

Pajor, A. M. 2006. Molecular properties of the SLC13 family of dicaboxylate and sulfate transporters. Eur. J. Physiol. 451:597-605.

Passonneau, L. V., and Lowry, O. H. 1993. Enzymatic Analysis. A Practical Approach. Humana Kozak Press, Totowa, NJ, U.S.A.

Pérembelon, M. C. M., and Kelman, A. 1980. Ecology of the soft rot erwinias. Annu. Rev. Phytopathol. 18:361-387.

Pos, K. M., Dimroth, P., and Bott, M. 1998. The Escherichia coli citrate carrier CitT: A member of a novel eubacterial transporter family related to the 2-oxoglutarate/malate translocator from spinach chloroplasts. J. Bacteriol. 180:4160-4165.

Saier, M. H. 2000. A functional-phylogenetic classification system for transmembrane solute transporters. Microbiol. Mol. Biol. Rev. 64:345411.

Sambrook, J., Fritsch, E. F., and Maniatis, T. 1989. Molecular Cloning: A Laboratory Manual. Cold Spring Harbor Laboratory Press, Cold Spring Harbor, NY, U.S.A.

Simmons, J. S. 1926. A culture medium for differentiating organisms of typhoid-colon aerogenes group and for certain fungi. J. Infect. Dis. 39:209-241.

Smid, E. J., Jansen, A. H., and Tuijn, C. J. 1993. Anaerobic nitrate respiration by Erwinia carotovora subsp. atroseptica during potato tuber invasion. Appl. Environ. Microbiol. 59:3648-3653.

Sturm, A., and Chrispeels, M. J. 1990. cDNA cloning of carrot extracellular $\beta$-fructosidase and its expression in response to wounding and bacterial infection. Plant Cell 2:1107-1119.

Tamir-Ariel, D., Navon, N., and Burdman, S. 2007. Identification of genes in Xanthomonas campestris pv. vesicatoria induced during its interaction with tomato. J. Bacteriol. 189:6359-6371.

Tang, D. J., He, Y. Q., Feng, J. X., He, B. R., Jiang, B. L., Lu, G. T., Chen, B., and Tang, J. L. 2005. Xanthomonas campestris pv. campestris possesses a single gluconeogenic pathway that is required for virulence. J. Bacteriol. 187:6231-6237.

Thomson, N. R., Cox, A., Bycroft, B. W., Stewart, G. S., Williams, P., and Salmond, G. P. 1997. The rap and hor proteins of Erwinia, Serratia, Yersinia: A novel subgroup in a growing superfamily of proteins regulating diverse physiological processes in bacterial pathogens. Mol. Microbiol. 26:531-544.

Tjaden, J., Möhlmann, T., Kampfenkel, K., Henrichs, G., and Neuhaus, H. E. 1998. Altered plastidic ATP/ADP-transporter activity influences potato (Solanum tuberosum) tuber morphology, yield and composition of tuber starch. Plant J. 16:531-540.

Truernit, E., Schmid, J., Epple, P., Illig, J., and Sauer, N. 1996. The sink specific and stress regulated Arabidopsis thaliana STP4 gene: Enhanced expression of a gene encoding a monosaccharide transporter by wounding, elicitors, and pathogen challenge. Plant Cell 8:2169-2182.

van der Rest, M. E., Molenaar, D., and Konings, W. N. 1992. Mechanism of $\mathrm{Na}(+)$-dependent citrate transport in Klebsiella pneumoniae. J. Bacteriol. 174:4893-4898.

Vasil, M. L. 2007. How we learnt about iron acquisition in Pseudomonas aeruginosa: A series of very fortunate events. Biometals 20:587-601.

Wassenaar, T. M., and Gaastra, W. 2001. Bacterial virulence: Can we draw the line? FEMS (Fed. Eur. Microbiol. Soc.) Microbiol. Lett. 201:1-7.

Weber, A., Menzlaff, E., Arbinger, B., Gutensohn, M., Eckerskorn, C., and Flügge, U. I. 1995. The 2-oxoglutarate/malate translocator of the chloroplasts envelope membranes: Molecular cloning of a transporter containing 12-helix motif and expression of the functional protein in yeast cells. Biochemistry 34:2621-2627.

Zhu, J. K. 2002. Salt and drought stress signal transduction in plants. Annu. Rev. Cell Biol. 53:247-273. 